\title{
BMJ Open What are effective approaches to increasing rates of organ donor registration among ethnic minority populations: a systematic review
}

\author{
Sarah Deedat, Charlotte Kenten, Myfanwy Morgan
}

To cite: Deedat S, Kenten C, Morgan M. What are effective approaches to increasing rates of organ donor registration among ethnic minority populations: a systematic review. BMJ Open 2013;3: 0003453

doi:10.1136/bmjopen-2013003453

- Prepublication history and additional material for this paper is available online. To view these files please visit the journal online (http://dx.doi.org/10.1136/ bmjopen-2013-003453).

Received 20 June 2013 Revised 4 September 2013 Accepted 9 October 2013

CrossMark

Department of Primary Care \& Public Health Sciences, King's College London, London, UK

Correspondence to Professor Myfanwy Morgan; myfanwy.morgan@kcl.ac.uk

\section{ABSTRACT}

Objectives: To identify effective interventions to increase organ donor registration and improve knowledge about organ donation among ethnic minorities in North America and the UK.

Design: Systematic review.

Data Sources: MEDLINE, EMBASE, PsycINFO, CINAHL and Cochrane Central searched up to November 2012, together with four trials databases and the grey literature.

Review methods: A systematic search followed by assessment of eligibility and quality. An interpretive and thematic approach to synthesis was undertaken. This examined the nature and delivery of interventions in relation to a range of outcomes: verified registration, changing knowledge and a measured shift towards greater readiness.

Results: 18 studies were included in the review, comprising educational and mass media interventions. Mass media interventions alone reported no significant change in the intention or willingness to register. Educational interventions either alone or combined with mass media approaches were more effective in increasing registration rates, with a strong interpersonal component and an immediate opportunity to register identified as important characteristics in successful change.

Conclusions: Effective interventions need to be matched to the populations' stage of readiness to register. Measured outcomes should include registration and shifts along the pathway towards this behavioural outcome.

\section{BACKGROUND}

There has been increasing debate in the UK regarding the merits of a potential shift towards a system of presumed consent for deceased organ donation to close the gap between the supply of organs for transplant and the numbers of organs required to meet the increasing demand. ${ }^{1}$ This gap is particularly significant for members of ethnic minority populations. In the UK, Black and South

\section{Strengths and limitations of this study}

- The first systematic review of evaluated interventions to increase organ donor registration and knowledge of organ donation among minority ethnic groups.

- The review examines both the outcomes achieved and issues of implementation to identify how and under what conditions a particular approach can be implemented to maximum effect.

- The number of evaluated interventions is currently small, with considerable variability in the study design, measures and outcomes assessed.

Asian individuals constitute $8.4 \%$ of the population $^{2}$ but represent $4 \%$ of organ donors for whom ethnicity is recorded and $20 \%$ of the active kidney transplant waiting list. ${ }^{3}$ Similarly, in the USA, African Americans account for $13 \%$ of the population but constitute $34 \%$ of those waiting for a kidney, ${ }^{4}$ while overall ethnic minorities account for $56.3 \%$ of those waiting for a transplant in the USA. ${ }^{5}$

The high level of unmet need for transplantation among British and American ethnic minority populations is influenced by increased risks of end-stage renal failure and thus a high need for kidney transplantation among minority ethnic groups. This low donation rate is of particular significance given the greater prevalence among minority ethnic groups of blood groups and human leucocyte antigen types that are less common in the general population. The donation rate among minority ethnic groups has in turn been shown to be influenced by a number of modifiable barriers, including lack of knowledge of the need for donors and how to register as a donor, less favourable cultural and religious beliefs, and a lack of trust in health professionals and the fairness of the organ allocation system. ${ }^{6}$ 
The UK's Organ Donation Taskforce recognised an urgent need to identify and implement the most effective methods to promote organ donation and registration to the public generally and ethnic minority populations specifically. ${ }^{7}$ However, despite mass media campaigns and some community engagement activities, the proportion of the population on the Organ Donor Register has only increased from $25 \%$ in 2008 to $30 \%$ in 2012, while the actual number of minority ethnic registrants remains small. $^{8}$

This review systematically assesses the best available evidence to determine the effectiveness of interventions designed to improve rates of registration and address poor knowledge to donation among ethnic minority populations. It also examines issues of implementation and seeks to identify how, where and under what conditions a particular approach can be implemented to maximum effect.

\section{METHODS}

\section{Systematic search}

The following databases were initially searched in December 2009 and refreshed in November 2012: MEDLINE, EMBASE, PsycINFO, CINAHL and Cochrane Central. Trials databases were also searched for relevant studies as was the academic and grey literature using search engines, hand checking relevant publications and direct contact with experts in the field (box 1).

The inclusion criteria focused on intervention studies in North America and the UK that were designed to

\section{Box 1 Systematic search}

\section{Sources}

Databases searched: MEDLINE (Ovid), EMBASE (Ovid), PsycINFO (Ovid), CINAHL (Ebso), Cochrane Central Pubmed Trials databases searched:

UKCRN, ClincialTrials.gov, WHO international Clinical Trials Registry Platform and Health Service Research Projects in Progress.

Websites searched for in the grey literature:

National Health Service Blood and Transplant-http://www. nhsbt.nhs.uk

Department of Health (UK)-http://www.dh.gov.uk

Kidney Research (UK)-http://www.kidneyresearch.org.uk

US Department of Transplant (funded studies) http://www. organdonor.gov/dtcp/behavior.html

2. Inclusion critera:

Country: UK, USA

Date of publication: 1980-2012

Ethnicity: Visible ethnic minority

Design: Intervention study, evaluation study

Outcomes: Verified registration, willingness/intent to register, change in registration rates

Participants: Adults and school age children

Setting: Community

Full search terms are available in the online supplementary material. change the rates of registration, intention/willingness to become a donor or knowledge about organ donation and focused on visible ethnic minorities (box 1).

A scoping search was initially run in MEDLINE and then further developed, revised and rerun and subsequently adapted for alternative databases. Ethnicity was defined as a visible (non-white) ethnic minority, with specific ethnic categories being those attributed, with a range of terms required to identify the appropriate ethnic minority populations. Table 1 provides an overview of included studies and the databases from which they were identified.

\section{Relevance and quality assessment}

Following initial deduplication, 557 articles remained (see figure 1). Two authors (SD and CK) independently reviewed the title and abstract of all citations identified and applied the exclusion criteria. Where information was not sufficient, the full article was retrieved for review. Where interventions were not targeted specifically at ethnic minorities, studies were included if subgroup analysis by ethnicity was conducted. Studies were excluded if they did not include original data or reported a meeting abstract only. Articles rejected at this stage were mainly cross-sectional studies that did not report an intervention to either increase registration or address knowledge gaps about organ donation in ethnic minority populations.

Two members of the research team independently scored the included articles for quality (SD and MM). Quality assessment was guided by the 'Assessment Tool for Quantitative Studies' (http://www.city.hamilton.on. $\mathrm{ca} /$ phcs/EPHPP), recommended by the Cochrane Handbook for the quality assessment of reviews in public health and health promotion. This tool is applicable to randomised controlled trials, quasi-experimental studies and uncontrolled studies ${ }^{9}$ and both content and construct validity have been established. ${ }^{10}$ Using this assessment tool, five articles were rated as 'strong', having four or more of the six components rated as strong with no weak ratings, and were all cluster randomised trials. Ten studies were 'moderate' with less than four components rated as strong and one as weak, and three articles had two or more components rated as 'weak' and were scored as such. Critical reflection on the quality review process led us to also consider complementary criteria set out by the Medical Research Council for the development and evaluation of complex interventions. ${ }^{11}$ This led to further assessment of theoretical quality in terms of how the intervention was expected to cause change and the quality of implementation in terms of whether there was standardisation of delivery through study design and/or facilitator training (see table 2).

\section{Data synthesis}

Wide variations in outcomes, populations and study design of included studies precluded meta-analysis. An 
Table 1 Overview of studies included in the review

\begin{tabular}{|c|c|c|c|c|c|c|c|}
\hline $\begin{array}{l}\text { Author and } \\
\text { country }\end{array}$ & $\begin{array}{l}\text { Demographics } \\
\text { sample size }(n)\end{array}$ & Study design & Mode of delivery & Results & Outcomes & $\begin{array}{l}\text { Theoretical } \\
\text { framework }\end{array}$ & Database \\
\hline \multicolumn{8}{|l|}{ Education } \\
\hline $\begin{array}{l}\text { Allen and } \\
\text { Stillwater, } \\
\text { USA }\end{array}$ & $\begin{array}{l}\text { Alaskan native } \\
\mathrm{N}=54 \text { Health } \\
\text { staff } \\
\mathrm{N}=<200 \\
\text { students }\end{array}$ & $\begin{array}{l}\text { Before and after } \\
\text { study }\end{array}$ & $\begin{array}{l}\text { PowerPoint } \\
\text { presentation and video } \\
\text { focused on issues } \\
\text { about OD and Alaskan } \\
\text { natives }\end{array}$ & $\begin{array}{l}\text { Improved knowledge } \\
\text { and positive attitude } \\
\text { towards donation and } \\
\text { intention to register post } \\
\text { test }\end{array}$ & $\begin{array}{l}\text { Knowledge and } \\
\text { intention to register } \\
\text { as a donor }\end{array}$ & Not mentioned & $\begin{array}{l}\text { Hand } \\
\text { search of } \\
\text { book }\end{array}$ \\
\hline $\begin{array}{l}\text { Alvaro et al, } \\
\text { USA } \\
\text { (pertains to } \\
\text { study II } \\
\text { reported in } \\
\text { paper) }\end{array}$ & Hispanic & $\begin{array}{l}\text { Before and after } \\
\text { study }\end{array}$ & $\begin{array}{l}\text { On alternate weeks, } \\
\text { employees of the local } \\
\text { organ procurement } \\
\text { organisation offered the } \\
\text { attendees at a flea } \\
\text { market an immediate } \\
\text { opportunity to register } \\
\text { or information about } \\
\text { organ donation }\end{array}$ & $\begin{array}{l}\text { Participants offered an } \\
\text { immediate opportunity to } \\
\text { register rather than just } \\
\text { information about OD } \\
\text { were significantly more } \\
\text { likely to register ( } 86 \% \text { vs } \\
54 \% \text { ) }\end{array}$ & Verified registration & $\begin{array}{l}\text { The IFF model } \\
\text { (Immediate } \\
\text { opportunity, } \\
\text { information, focused } \\
\text { engagement and } \\
\text { favourable } \\
\text { activation) }\end{array}$ & MEDLINE \\
\hline $\begin{array}{l}\text { Andrews } \\
\text { et } a l,{ }^{13} \text { USA }\end{array}$ & $\begin{array}{l}\text { African } \\
\text { American } \\
\text { Intervention } \\
n=622 \\
\text { Control } n=632\end{array}$ & $\begin{array}{l}\text { Cluster } \\
\text { randomised }\end{array}$ & $\begin{array}{l}\text { Members of the } \\
\text { congregation undertook } \\
\text { discussions with lay } \\
\text { health advisors about } \\
\text { organ donation. } \\
\text { DVD designed to } \\
\text { address OD barriers for } \\
\text { African Americans }\end{array}$ & $\begin{array}{l}\text { Increase in verified } \\
\text { enrolment on donor } \\
\text { registry in intervention } \\
\text { group. No increase in } \\
\text { knowledge observed }\end{array}$ & $\begin{array}{l}\text { Verified enrolment } \\
\text { on donor registry }\end{array}$ & Not mentioned & PubMed \\
\hline $\begin{array}{l}\text { A Warrens, } \\
\text { personal } \\
\text { communication, } \\
2013 \text { UK }\end{array}$ & $\begin{array}{l}\text { Multiethnic } \\
\mathrm{N}=806\end{array}$ & $\begin{array}{l}\text { Cross-sectional } \\
\text { evaluation }\end{array}$ & $\begin{array}{l}\text { Peer educators trained } \\
\text { to deliver health } \\
\text { promotion about } O D\end{array}$ & $\begin{array}{l}\text { Increase in the } \\
\text { percentage of people } \\
\text { signed up to the organ } \\
\text { donor register }\end{array}$ & Registration & Not mentioned & $\begin{array}{l}\text { Author } \\
\text { contact }\end{array}$ \\
\hline $\begin{array}{l}\text { Callender } \\
\text { et } a{ }^{25}{ }^{25} \text { USA }\end{array}$ & $\begin{array}{l}\text { Multiethnic } \\
\mathrm{N}=914\end{array}$ & $\begin{array}{l}\text { Before and after } \\
\text { study }\end{array}$ & $\begin{array}{l}\text { Presentation about } \\
\text { organ donation } \\
\text { delivered by transplant } \\
\text { recipients, donors, } \\
\text { individuals on } \\
\text { transplant lists } \\
\text { healthcare } \\
\text { professionals who are } \\
\text { ethnically similar to the } \\
\text { target population. }\end{array}$ & $\begin{array}{l}\text { Improvements in } \\
\text { knowledge and attitudes } \\
\text { towards OD, high } \\
\text { reporting of willingness } \\
\text { to discuss OD with } \\
\text { family }\end{array}$ & $\begin{array}{l}\text { Willingness to } \\
\text { donate organs for } \\
\text { oneself and loved } \\
\text { ones after death } \\
\text { No valid measures } \\
\text { to assess attitudes } \\
\text { to OD }\end{array}$ & Not mentioned & EMBASE \\
\hline $\begin{array}{l}\text { Thornton } \\
\text { et al },{ }^{17} \text { USA }\end{array}$ & $\begin{array}{l}\text { Multiethnic } \\
\text { Intervention } \\
n=443 \\
\text { Control } n=509\end{array}$ & $\begin{array}{l}\text { Cluster } \\
\text { randomised }\end{array}$ & $\begin{array}{l}5 \text { min Video about OD } \\
\text { prior to collecting } \\
\text { driver's licence. } \\
\text { Controls obtained }\end{array}$ & $\begin{array}{l}\text { Cases more likely to } \\
\text { register as donors } \\
\text { compared to controls } \\
\text { ( } 76 \% \text { vs } 54 \%)\end{array}$ & $\begin{array}{l}\text { Verified enrolment } \\
\text { on donor registry }\end{array}$ & Not Mentioned & EMBASE \\
\hline
\end{tabular}




\begin{tabular}{|c|c|c|c|c|c|c|c|}
\hline $\begin{array}{l}\text { Author and } \\
\text { country }\end{array}$ & $\begin{array}{l}\text { Demographics } \\
\text { sample size (n) }\end{array}$ & Study design & Mode of delivery & Results & Outcomes & $\begin{array}{l}\text { Theoretical } \\
\text { framework }\end{array}$ & Database \\
\hline & & & $\begin{array}{l}\text { licence in the usual } \\
\text { manner. }\end{array}$ & & & & \\
\hline $\begin{array}{l}\text { Fahrenwald } \\
\text { et } a{ }^{28},{ }^{28} \text { USA }\end{array}$ & $\begin{array}{l}\text { American } \\
\text { Indians } \\
\mathrm{N}=1580\end{array}$ & $\begin{array}{l}\text { Before and after } \\
\text { study }\end{array}$ & $\begin{array}{l}\text { Out-reach coordinators } \\
\text { facilitate delivery to } \\
\text { small groups who were } \\
\text { required to read and } \\
\text { discuss a } 1 \text { page } \\
\text { brochure. This was } \\
\text { followed by a } 13 \text { min } \\
\text { video and a group } \\
\text { discussion facilitated by } \\
\text { the coordinator }\end{array}$ & $\begin{array}{l}\text { Significant change in } \\
\text { stage of motivational } \\
\text { readiness to become an } \\
\text { OD postintervention }\end{array}$ & $\begin{array}{l}\text { Stage of } \\
\text { motivational } \\
\text { readiness to serve } \\
\text { as an organ donor }\end{array}$ & $\begin{array}{l}\text { Transtheoretical } \\
\text { model of behaviour } \\
\text { change }\end{array}$ & PubMed \\
\hline $\begin{array}{l}\text { Resnicow } \\
\text { et al, }{ }^{12} \text { USA }\end{array}$ & $\begin{array}{l}\text { African } \\
\text { American } \\
\text { Intervention } \\
n=1370 \\
\text { Control } n=1419\end{array}$ & $\begin{array}{l}\text { Cluster } \\
\text { randomised }\end{array}$ & $\begin{array}{l}\text { Hairstylists trained as } \\
\text { lay health advisors } \\
\text { used motivational } \\
\text { interviewing to discuss } \\
\text { OD with participants }\end{array}$ & $\begin{array}{l}\text { Participants receiving } \\
\text { the intervention were } 4 \\
\text { times more likely to join } \\
\text { the register than the } \\
\text { controls }\end{array}$ & $\begin{array}{l}\text { Self-reported } \\
\text { donation status } \\
\text { Verified enrolment } \\
\text { on state registry }\end{array}$ & Not Mentioned & $\begin{array}{l}\text { PubMed } \\
\text { and } \\
\text { EMBASE }\end{array}$ \\
\hline $\begin{array}{l}\text { Salim et } a l,{ }^{24} \\
\text { USA }\end{array}$ & $\begin{array}{l}\text { Hispanic } \\
\mathrm{N}=341\end{array}$ & $\begin{array}{l}\text { Before and after } \\
\text { study }\end{array}$ & $\begin{array}{l}\text { Presentation about the } \\
\text { need for transplant and } \\
\text { information about } \\
\text { donation lead by a local } \\
\text { organ procurement } \\
\text { organisation }\end{array}$ & $\begin{array}{l}\text { Increase in knowledge, } \\
\text { perceptions and beliefs. } \\
\text { No difference } \\
\text { willingness to discuss } \\
\text { donation with family or } \\
\text { intent to donate }\end{array}$ & $\begin{array}{l}\text { Change in } \\
\text { knowledge and } \\
\text { attitude } \\
\text { Donation intent }\end{array}$ & Not mentioned & PubMed \\
\hline $\begin{array}{l}\text { Cárdenas } \\
\text { et al, }{ }^{18} \text { USA }\end{array}$ & $\begin{array}{l}\text { Multiethnic } \\
\text { Intervention } \\
n=96 \text { Control } \\
n=91\end{array}$ & $\begin{array}{l}\text { Cluster } \\
\text { randomised }\end{array}$ & $\begin{array}{l}\text { Transplant surgeons } \\
\text { and young recipients } \\
\text { gave a presentation } \\
\text { followed by a } Q \& A \\
\text { session and a video }\end{array}$ & $\begin{array}{l}\text { Knowledge increase } \\
\text { postintervention was the } \\
\text { strongest predictor of } \\
\text { positive change in } \\
\text { opinion about OD }\end{array}$ & $\begin{array}{l}\text { Knowledge, } \\
\text { attitudes and } \\
\text { awareness of OD }\end{array}$ & None mentioned & MEDLINE \\
\hline $\begin{array}{l}\text { Feeley et al, }{ }^{19} \\
\text { USA }\end{array}$ & Multiethnic & $\begin{array}{l}\text { Before and after } \\
\text { study }\end{array}$ & $\begin{array}{l}\text { Peer educators } \\
\text { delivered a range of } \\
\text { campus-based } \\
\text { activities }\end{array}$ & $\begin{array}{l}\text { Increased donor } \\
\text { registration }\end{array}$ & $\begin{array}{l}\text { Self-reported } \\
\text { registration }\end{array}$ & Not mentioned & $\begin{array}{l}\text { Embase, } \\
\text { MEDLINE, } \\
\text { PubMed }\end{array}$ \\
\hline $\begin{array}{l}\text { Arriola et al, }{ }^{14} \\
\text { USA }\end{array}$ & $\begin{array}{l}\text { African } \\
\text { American } \\
\text { Intervention } \\
n=175 \\
\text { Control } n=162\end{array}$ & $\begin{array}{l}\text { Cluster } \\
\text { randomised }\end{array}$ & $\begin{array}{l}\text { Video and written } \\
\text { materials mailed to } \\
\text { participants }\end{array}$ & $\begin{array}{l}\text { Greater readiness to } \\
\text { sign a donor card, } \\
\text { register through a } \\
\text { driver's licence or talk to } \\
\text { family about wishes in } \\
\text { the intervention group }\end{array}$ & $\begin{array}{l}\text { Readiness to } \\
\text { express donation } \\
\text { intent through a } \\
\text { driver's licence, } \\
\text { donor card and } \\
\text { discussion with } \\
\text { family }\end{array}$ & $\begin{array}{l}\text { Transtheoretical } \\
\text { model of behaviour } \\
\text { change }\end{array}$ & $\begin{array}{l}\text { EMBASE, } \\
\text { PubMed } \\
\text { and } \\
\text { MEDLINE }\end{array}$ \\
\hline \multicolumn{8}{|l|}{ Media } \\
\hline $\begin{array}{l}\text { Alvaro et } a l,{ }^{31} \\
\text { USA }\end{array}$ & $\begin{array}{l}\text { Hispanic } \\
\mathrm{N}=2401\end{array}$ & $\begin{array}{l}\text { Before and after } \\
\text { study }\end{array}$ & $\begin{array}{l}4 \times 30 \text { s television } \\
2 \times 60 \text { s radio ads. }\end{array}$ & $\begin{array}{l}\text { Greater reporting of } \\
\text { prodonation beliefs and }\end{array}$ & $\begin{array}{l}\text { Self-reported } \\
\text { registration status }\end{array}$ & Not mentioned & \\
\hline
\end{tabular}




\begin{tabular}{|c|c|c|c|c|c|c|c|}
\hline $\begin{array}{l}\text { Author and } \\
\text { country }\end{array}$ & $\begin{array}{l}\text { Demographics } \\
\text { sample size (n) }\end{array}$ & Study design & Mode of delivery & Results & Outcomes & $\begin{array}{l}\text { Theoretical } \\
\text { framework }\end{array}$ & Database \\
\hline & & & $\begin{array}{l}\text { These highlighted } \\
\text { positive impact of } \\
\text { transplant on Hispanic } \\
\text { individuals and } \\
\text { demonstrated the } \\
\text { substantial efforts } \\
\text { medics undertake to } \\
\text { save the life of a } \\
\text { potential donor }\end{array}$ & $\begin{array}{l}\text { family discussion } \\
\text { postintervention }\end{array}$ & $\begin{array}{l}\text { No validated } \\
\text { measures of attitude } \\
\text { and willingness to } \\
\text { OD }\end{array}$ & & $\begin{array}{l}\text { EMBASE } \\
\text { and } \\
\text { MEDLINE }\end{array}$ \\
\hline $\begin{array}{l}\text { Frates et al, } \\
\text { USA }\end{array}$ & $\begin{array}{l}\text { Hispanic } \\
\mathrm{N}=4500\end{array}$ & $\begin{array}{l}\text { Before and after } \\
\text { study }\end{array}$ & $\begin{array}{l}\text { Prime time television } \\
\text { and radio slots }\end{array}$ & $\begin{array}{l}\text { Year on year increase in } \\
\text { Hispanic OD consent } \\
\text { rates (overall } 10 \% \\
\text { increase). } \\
\text { Increase in knowledge/ } \\
\text { attitudes }\end{array}$ & $\begin{array}{l}\text { Consent rates from } \\
\text { organ procurement } \\
\text { organisation } \\
\text { No valid measures } \\
\text { to assess attitudes } \\
\text { to OD }\end{array}$ & $\begin{array}{l}\text { Transtheoretical } \\
\text { model }\end{array}$ & $\begin{array}{l}\text { EMBASE, } \\
\text { MEDLINE } \\
\text { and } \\
\text { PsycINFO }\end{array}$ \\
\hline $\begin{array}{l}\text { Salim et } a l,{ }^{30} \\
\text { USA }\end{array}$ & $\begin{array}{l}\text { Hispanic } \\
\mathrm{N}=1052\end{array}$ & $\begin{array}{l}\text { Before and after } \\
\text { study }\end{array}$ & $\begin{array}{l}\text { Prime time television } \\
\text { and radio slots }\end{array}$ & $\begin{array}{l}\text { Improved knowledge } \\
\text { postcampaign when } \\
\text { compared to baseline }\end{array}$ & $\begin{array}{l}\text { Awareness, } \\
\text { perception and } \\
\text { belief about OD }\end{array}$ & Not mentioned & $\begin{array}{l}\text { EMBASE } \\
\text { and } \\
\text { MEDLINE }\end{array}$ \\
\hline $\begin{array}{l}\text { Radosevich } \\
\text { et } a{ }^{16}{ }^{16} \text { USA }\end{array}$ & $\begin{array}{l}\text { African } \\
\text { American } \\
\mathrm{N}=465\end{array}$ & $\begin{array}{l}\text { Before and after } \\
\text { study }\end{array}$ & $\begin{array}{l}\text { Media campaign } \\
\text { conveyed through } \\
\text { television, radio, } \\
\text { targeted print media. } \\
\text { Donor families and } \\
\text { healthcare } \\
\text { professionals were } \\
\text { interviewed on } \\
\text { television and radio }\end{array}$ & $\begin{array}{l}\text { Significant increase in } \\
\text { knowledge and attitude } \\
\text { about organ donation } \\
\text { postcampaign } \\
\text { No significant change in } \\
\text { intention and willingness } \\
\text { to become a donor }\end{array}$ & $\begin{array}{l}\text { Self-reported } \\
\text { registration } \\
\text { Change in } \\
\text { knowledge, attitudes } \\
\text { and willingness to } \\
\text { become a donor }\end{array}$ & $\begin{array}{l}\text { Theory of Reasoned } \\
\text { Action }\end{array}$ & $\begin{array}{l}\text { Hand } \\
\text { Search of } \\
\text { Book }\end{array}$ \\
\hline \multicolumn{8}{|c|}{ Media and education } \\
\hline $\begin{array}{l}\text { Harrison } \\
\text { et al, }{ }^{15} \text { USA }\end{array}$ & $\begin{array}{l}\text { African } \\
\text { American } \\
\mathrm{N}=626771\end{array}$ & $\begin{array}{l}\text { Before and after } \\
\text { study }\end{array}$ & $\begin{array}{l}\text { Billboards in the vicinity } \\
\text { of vehicle licensing } \\
\text { offices and radio } \\
\text { adverts. Trained } \\
\text { volunteers with links to } \\
\text { donation at vehicle } \\
\text { licensing offices to } \\
\text { engage in conversation }\end{array}$ & $\begin{array}{l}\text { Overall } 700 \% \text { increase } \\
\text { above baseline in sign } \\
\text { up to the donor register. } \\
\text { The magnitude of the } \\
\text { increase was greatest } \\
\text { when one-to-one } \\
\text { promotion was } \\
\text { combined with other } \\
\text { medium }\end{array}$ & Verified registration & $\begin{array}{l}\text { Communication } \\
\text { design }\end{array}$ & PubMed \\
\hline $\begin{array}{l}\text { Hebert et } a l_{,}^{32} \\
\text { USA }\end{array}$ & $\begin{array}{l}\text { Chinese } \\
\text { American } \\
\mathrm{N}=1134\end{array}$ & $\begin{array}{l}\text { Before and after } \\
\text { study }\end{array}$ & $\begin{array}{l}\text { Media campaign } \\
\text { Grass roots community } \\
\text { outreach }\end{array}$ & $\begin{array}{l}\text { Significant increase in } \\
\text { stated intention to } \\
\text { donate in the } \\
\text { intervention area vs the } \\
\text { control area }\end{array}$ & $\begin{array}{l}\text { Joining a donor } \\
\text { registry } \\
\text { Express a desire to } \\
\text { become an organ } \\
\text { donor } \\
\text { Communicating } \\
\text { wishes to family }\end{array}$ & Not mentioned & $\begin{array}{l}\text { Hand } \\
\text { search of } \\
\text { book }\end{array}$ \\
\hline
\end{tabular}




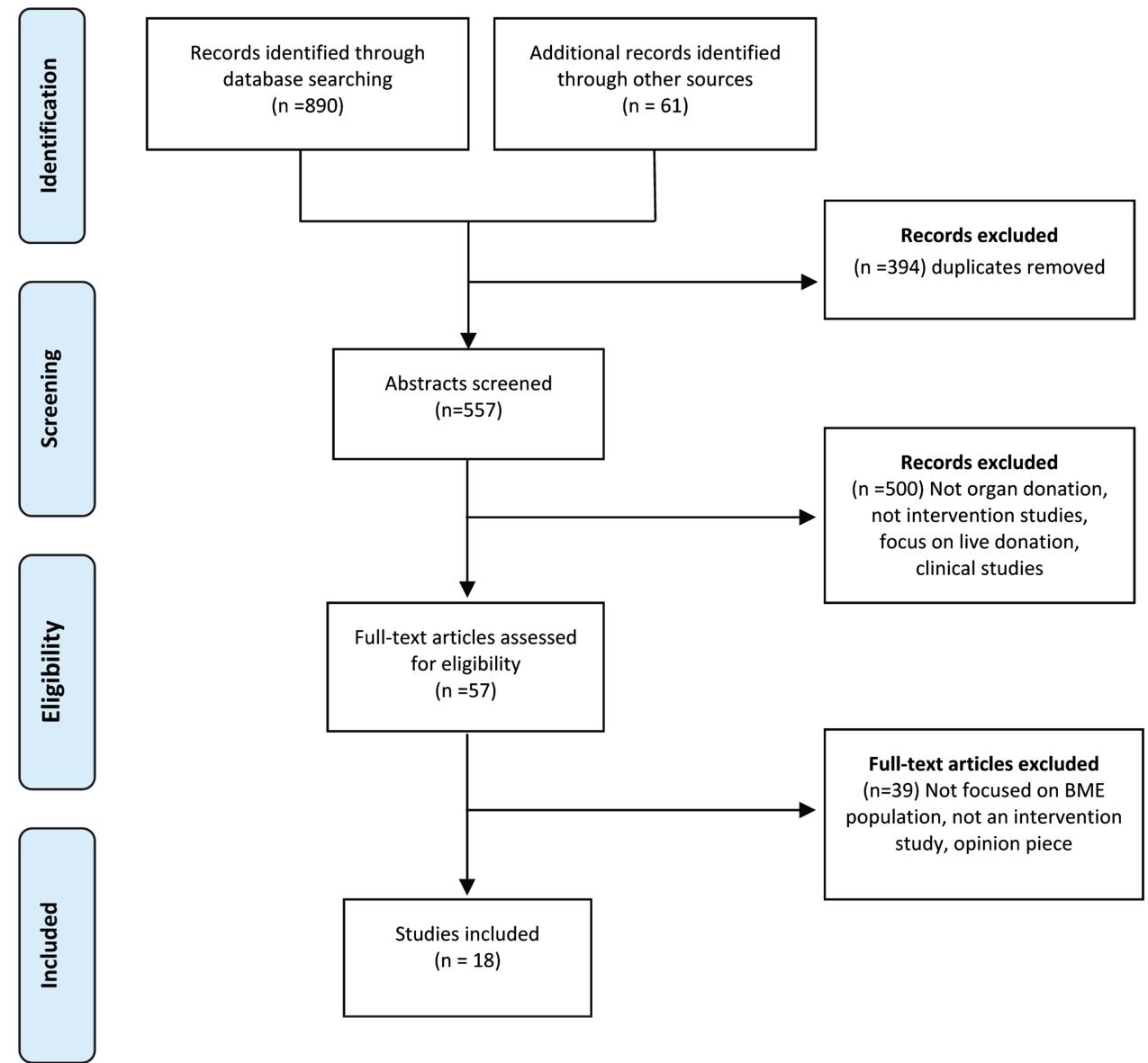

Figure 1 Selection of studies for inclusion in systematic review of interventions to increase organ donor registration among ethnic minority populations.

interpretive and thematic approach to synthesis was therefore undertaken and examined the nature and delivery of interventions as well as the outcomes achieved. Studies were initially classified by: date, country, population studied and intervention type and study design. The second step involved classifying the media and education interventions in terms of the aims of the interventions and the outcomes achieved. Third, we examined the relationship between characteristics of the interventions from the outcomes. Data were extracted into tables and these were verified by two of the authors (SD and MM).

\section{RESULTS}

\section{Study characteristics}

The 18 included studies were conducted between 1993 and 2012. These either evaluated the effects of an ethnically targeted mass media campaign or communitybased education. With the exception of one UK study, all were undertaken with ethnic minority populations in the USA, mainly African Americans or Hispanics. ${ }^{12-16}$ Whereas most interventions adopted a pre-evaluation and postevaluation design (table 1), studies published since 2009 mainly employed a cluster randomised design. ${ }^{12-14} 1718$ Outcomes assessed were verified registration, self-reported registration status or knowledge about organ donation (see table 1).

\section{Educational interventions}

Eleven articles reported educational interventions. Recruitment was mainly through or conducted at places of worship and/or educational establishments, and delivered by a range of individuals including recipient families, trained lay individuals or organ transplant and procurement staff. Six studies were designed for a specific ethnic group, with the remainder aimed at a multiethnic audience (see table 2)

\section{Verified registration}

Three cluster randomised trials reported an outcome of verified enrolment on a donor register. ${ }^{12}{ }^{13} 17$ Two of these studies trained individuals embedded within community settings to deliver the intervention, ${ }^{12}{ }^{13}$ with both these interventions having a strong interpersonal element and being delivered in familiar settings of a local church or hairdresser. Peer educators in Andrews' study ${ }^{13}$ mostly had a medical background and were involved in a Church Health Committee. They undertook a $4 \mathrm{~h}$ training package that comprised general information about 


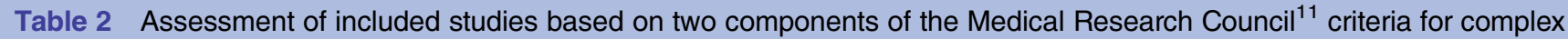
interventions

\begin{tabular}{|c|c|c|}
\hline Authors & $\begin{array}{l}\text { Theoretical } \\
\text { quality }\end{array}$ & Standardisation of delivery \\
\hline A Warrens, personal & Minimally & Authors allow for and explain variation in intervention delivery \\
\hline $\begin{array}{l}\text { communication, } 2013 \\
\text { Allen and Stillwater }\end{array}$ & $\begin{array}{l}\text { grounded } \\
\text { Minimally } \\
\text { grounded }\end{array}$ & $\begin{array}{l}\text { Standard training offered to educators delivering intervention } \\
\text { Authors indicate variation }\end{array}$ \\
\hline Alvaro et $a l^{\beta 1}$ & $\begin{array}{l}\text { Moderately } \\
\text { grounded }\end{array}$ & Strict standardisation (due to intervention design) \\
\hline Alvaro et afo & Well grounded & $\begin{array}{l}\text { Strict standardisation-authors undertook unannounced site visits and } \\
\text { developed standard reporting tools for completion at intervention sites }\end{array}$ \\
\hline Andrews et $a l^{13}$ & $\begin{array}{l}\text { Moderately } \\
\text { grounded }\end{array}$ & Authors indicate variation \\
\hline Arriola et $a l^{14}$ & Well grounded & Strict standardisation \\
\hline Callender et a ${ }^{25}$ & Well grounded & Authors indicate variation \\
\hline Cárdenas et al ${ }^{18}$ & $\begin{array}{l}\text { Moderately } \\
\text { grounded }\end{array}$ & Strict standardisation \\
\hline Thornton et al ${ }^{17}$ & $\begin{array}{l}\text { No theoretical } \\
\text { grounding }\end{array}$ & Strict standardisation \\
\hline Fahrenwald et $a^{p 8}$ & Well grounded & Strict standardisation \\
\hline Feeley et $a l^{19}$ & $\begin{array}{l}\text { Moderately } \\
\text { grounded }\end{array}$ & Authors allow for and explain variation \\
\hline Frates et $a P^{29}$ & $\begin{array}{l}\text { Moderately } \\
\text { grounded }\end{array}$ & Strict standardisation (due to intervention design) \\
\hline Harrison et $a l^{15}$ & Well grounded & $\begin{array}{l}\text { Strict standardisation of media and print info. Variation but no } \\
\text { explanation or assessment of variation in interpersonal elements }\end{array}$ \\
\hline Hebert et $a{ }^{\beta 2}$ & $\begin{array}{l}\text { Moderately } \\
\text { grounded }\end{array}$ & Strict standardisation (due to intervention design) \\
\hline Radosevich et $a l^{15}$ & $\begin{array}{l}\text { Moderately } \\
\text { grounded }\end{array}$ & Strict standardisation due to intervention design) \\
\hline Resnicow et al ${ }^{12}$ & $\begin{array}{l}\text { Moderately } \\
\text { grounded }\end{array}$ & $\begin{array}{l}\text { Strict standardisation. Standard training offered to educators delivering } \\
\text { intervention }\end{array}$ \\
\hline Salim et $a^{\beta 0}$ & $\begin{array}{l}\text { Minimally } \\
\text { grounded }\end{array}$ & Strict standardisation (due to intervention design) \\
\hline Salim et $a$ R $^{4}$ & $\begin{array}{l}\text { Minimally } \\
\text { grounded }\end{array}$ & Strict standardisation \\
\hline
\end{tabular}

organ donation and tips on integrating the topic into church discussions. In Resnicow's study, ${ }^{12}$ hair stylists were trained over 2 days in practical techniques to facilitate communication (motivational interviewing) and general organ donation information. There were wide variations in the duration of these study interventions: participants in the Church study were exposed over a period of 12 months, while interventions with a hair stylist ran for 1 session/month for 4 months. In contrast, the third intervention in this category did not have a strong interpersonal element, and trialled the use of a 5 min educational film to address common barriers to organ donation that was targeted at those attending the state vehicle licensing office. ${ }^{17}$ Across all three interventions, the exposed group were significantly more likely to register than the controls, although the effects of the video intervention among vehicle licensing office attendees were significant for White and African Americans but not Hispanic participants, ${ }^{17}$ possibly reflecting their small number $(\mathrm{n}=-28)$.
Further, three community educational studies based on a follow-up or cross-sectional design reported strategies to increase organ donor registration. Feeley et $a l^{19}$ reported a $1.6 \%$ increase in new organ donor registrations following campus-led peer education among students from six university campuses in the USA that were selected as having a high percentage of minority student enrolment. Similarly, a study in Arizona focused on Hispanics attending a large community event found that advertising and offering an immediate opportunity to register produced significantly greater registration rates compared with the use of a generic slogan and offering general information about organ donation $(86 \%$ vs $54 \%) .{ }^{20} \mathrm{~A}$ further UK community-based educational intervention study focused on attendees at a range of venues and community events selected to maximise engagement with Black and minority (BME) communities (A Warrens, personal communication, 2013). The authors report that following discussion with a trained BME Peer Educator and the availability of facilities for 
Table 3 Absolute difference $(95 \% \mathrm{Cl})$ between intervention and control groups for verified registration across ethnic groups

Table 3 Absolute difference ( $95 \% \mathrm{Cl})$ between intervention and control groups for verfied registration across ethnic groups

\begin{tabular}{|c|c|c|c|c|}
\hline \multirow[b]{2}{*}{ Study } & \multirow[b]{2}{*}{ Target population/setting } & \multirow[b]{2}{*}{ Intervention } & \multicolumn{2}{|c|}{ African American Hispanic } \\
\hline & & & Absolute differenc & $(\mathrm{Cl} 95 \%)$ \\
\hline $\begin{array}{l}\text { Resnicow } \\
\text { et } a l^{12 \star}\end{array}$ & $\begin{array}{l}\text { African American setting: } \\
\text { Hair Dressers }\end{array}$ & $\begin{array}{l}\text { Intervention: Brief motivational } \\
\text { intervention delivered by hairdresser }\end{array}$ & $\begin{array}{l}2.8(2.2 \text { to } 3.2) \\
p<0.0001\end{array}$ & \\
\hline $\begin{array}{l}\text { Thornton } \\
\text { et } a l^{17}\end{array}$ & $\begin{array}{l}\text { All ethnic groups including } \\
\text { white setting: outside motor } \\
\text { Vehicle registration office }\end{array}$ & $\begin{array}{l}\text { Intervention: } 5 \text { min video addressing } \\
\text { ethnic concerns about OD }\end{array}$ & $\begin{array}{l}22(9 \text { to } 35) \\
p=0.0009\end{array}$ & $\begin{array}{l}29(-8 \text { to } 65), \\
p=0.12\end{array}$ \\
\hline $\begin{array}{l}\text { Andrews } \\
\text { et } a l^{13}\end{array}$ & $\begin{array}{l}\text { African American Setting: } \\
\text { African American churches }\end{array}$ & $\begin{array}{l}\text { Intervention: Focused discussions about } \\
\text { donation followed by a DVD aimed at } \\
\text { African American concerns about } \\
\text { donation }\end{array}$ & $\begin{array}{l}18.7(16.6 \text { to } 20.8) \\
p<0.0001\end{array}$ & \\
\hline
\end{tabular}

registering, $9 \%$ of those not already on the Organ Donor Register joined on the day. The intervention was also shown to be most effective among those who had previously considered signing up but who did not know how to go about it. These community educational studies thus identify important influences on registration as both the individual's prior readiness and access to registration (table 3 ).

\section{Changing knowledge}

Previous research has shown that knowledge about organ donation is associated with attitudes, intention to donation and willingness to discuss organ donation intentions with family. ${ }^{21-23}$ Among the included studies, knowledge was assessed by asking participants to indicate whether a range of statements regarding organ donation were true or false. These studies conceived knowledge as comprising five facets (1) general knowledge about donation; (2) knowledge of the relevance of donation to the ethnic minority population; (3) knowledge about the procurement and allocation of organs; (4) religious and cultural knowledge about organ donation and (5) knowledge about the financial costs of organ donation. Presentations to participants were delivered by ethnic minority transplant surgeons and donor/recipient families. Interventions tended to be one-off and commonly lasted $1 \mathrm{~h}$, with immediate follow-up questionnaires administered to participants.

Two studies tested the relationship between knowledge about organ donation and willingness to become an organ donor. These studies found that significant improvements in knowledge increased the willingness among participants to state that they intended to register as a donor. Among Hispanic participants, knowledge relating to the fair allocation of organs was a significant independent predictor of willingness ${ }^{24}$ (see table 4), while among a multiethnic sample of high school students improvements in composite knowledge scores significantly predicted a willingness to donate organs in the intervention group. ${ }^{18}$
The remaining two studies assessed a range of knowledge items before and after the delivery of an educational intervention. In a multiethnic sample of adults, a significant increase in knowledge was achieved for half of all knowledge items (see table 4). ${ }^{25}$ Of particular note, African Americans who comprised $60 \%$ of the sample achieved the greatest change postintervention in relation to trust in doctors when compared to trust scores for other ethnic groups. Overall, postintervention, participants in this study reported being significantly more likely to state that they were willing to donate their own and their family's organs after death $(\mathrm{p}<0.000) .^{25}$ Unlike the aforementioned studies which focused on the lay population, Allen and Stillwater's ${ }^{26}$ holistic interventions addressed knowledge gaps and misinformation among Alaskan Community Health aides and school children. The authors do not report details about individual aspects of knowledge addressed but report a significant increase in knowledge among both students from $58 \%$ to $95 \%$ correct $(\mathrm{p}<0.0001)$ and community health practitioners $(\mathrm{p}<0.0001)$.

Table 4 shows the number of items where a significant increase in knowledge was observed post-test. All four interventions reported that it is possible to address knowledge deficits among participants. However, no assessment was made about the extent to which gains in knowledge are maintained and whether increased willingness necessarily results in actual donor registration.

\section{Measured shift towards greater readiness}

Two educational interventions were informed by the transtheoretical model (TTM) of behaviour change ${ }^{27}$ and measured change in an individual's 'readiness to become an organ donor'. ${ }^{28}$ Both studies aimed to measure change across the five TTM stages from precontemplation to maintenance (box 2). In Fahrenwald's study, $56.9 \%$ of participants progressed to a more advanced stage post-test and none regressed, while Arriola reported that intervention participants were 1.53 
Table 4 Educational interventions reporting change in knowledge about organ donation

\begin{tabular}{|c|c|c|c|c|c|}
\hline Study & Target population & $\begin{array}{l}\text { Duration and length of } \\
\text { follow-up } \\
\text { postintervention }\end{array}$ & $\begin{array}{l}\text { Number of items with } \\
\text { a significant } \\
\text { improvement post-test }\end{array}$ & $\begin{array}{l}\text { Percentage of items } \\
\text { where significant } \\
\text { increase in knowledge } \\
\text { recorded }\end{array}$ & \\
\hline $\begin{array}{l}\text { Cárdenas } \\
\text { et } a l^{18}\end{array}$ & $\begin{array}{l}\text { High school } \\
\text { students, } \\
\text { multiethnic }\end{array}$ & $\begin{array}{l}60 \text { min } \\
\text { Immediate follow-up }\end{array}$ & $12 / 16$ & 75 & $\begin{array}{l}\text { Greater improvements in composite knowledge } \\
\text { score predicted a willingness to donate in the } \\
\text { intervention group (OR 1.42, Cl 1.18-1.71, } \\
p<0.001 \text { ) }\end{array}$ \\
\hline $\begin{array}{l}\text { Callender } \\
\text { et } a^{{ }^{5}}\end{array}$ & Multi ethnic adults & $\begin{array}{l}\text { Not reported } \\
\text { Immediate follow-up }\end{array}$ & $4 / 8$ & 50 & $\begin{array}{l}\text { Significant improvement in } 4 \text { knowledge items } \\
\text { (1) Knowledge about higher rates of kidney } \\
\text { disease among BME (2) Longer wait times for } \\
\text { transplant for BME (3) less likely to believe } \\
\text { doctors would hasten death if they knew donor } \\
\text { status of patient } \\
\text { (4) Less likely to state that god needs 'whole' } \\
\text { bodies for the afterlife }\end{array}$ \\
\hline $\begin{array}{l}\text { Salim et al, } \\
\text { USA }^{24}\end{array}$ & Hispanic Adults & $45-60 \mathrm{~min}$ & $15 / 25$ & 60 & $\begin{array}{l}\text { Independent positive predictors of willingness to } \\
\text { donate: } \\
\text { (1) Knowledge of a national matching system } \\
\text { (AOR } 3.36, C l 1.43-7.88, p=0.005) \\
\text { (2) Not perceiving that wealthy people are more } \\
\text { likely to receive a transplant (AOR } 5.39,2.02- \\
14.37 p=0.0008 \text { ) }\end{array}$ \\
\hline \multirow[t]{2}{*}{$\begin{array}{l}\text { Allen and } \\
\text { Stillwater, } \\
\text { USA }\end{array}$} & $\begin{array}{l}\text { Alaskan Natives } \\
\text { School Children }\end{array}$ & Not specified & $n / r$ & $n / r$ & $\begin{array}{l}\text { Scores for knowledge about donation and } \\
\text { transplantation increased significantly pretest } \\
58 \% \text { correct vs } 95 \% \text { post-test } p<0.001 \\
\text { Students significantly more likely to state they } \\
\text { would be a donor } p=0.021\end{array}$ \\
\hline & $\begin{array}{l}\text { Community Health } \\
\text { Aids \& Practitioners } \\
\text { (adults) }\end{array}$ & $\begin{array}{l}3 \mathrm{~h} \text { presentation as part } \\
\text { of CPD }\end{array}$ & $n / r$ & $n / r$ & $\begin{array}{l}\text { Significant increase in factual knowledge score } \\
p<0.001-\text { mean knowledge scores doubled } \\
\text { post-test } \\
\text { Participants were significantly more likely to } \\
\text { report intent to sign a donor card post-test } \\
p=0.003 \\
\text { Significantly greater awareness of how and } \\
\text { where to get information about organ donation } \\
p<0.001\end{array}$ \\
\hline
\end{tabular}

AOR, adjusted OR; n/r, Not reported. 
Box 2 Prochaska and Velicer's Stages of Change ${ }^{27}$ adapted for Organ Donation

Precontemplation: Have not considered registering as an organ donor

- Contemplation: Considered organ donation, but not taken steps towards registration or addressing unresolved issues/ concerns

- Preparation: Able to recognise the benefits of registration and have taken action to find out more

- Action: Expressed their wishes about donation by either signing the organ donor register or discussed wishes with immediate family/kin

- Maintenance: Occasionally reinforce statement of wishes to family members/kin

times more likely to be in a later stage of readiness than control participants.

Collaboration with members of the targeted ethnic population was undertaken to ensure the relevance and acceptability of the intervention. For Arriola et $a l,{ }^{14}$ this involved a specific focus on religious objections to organ donation, involvement of the church pastors and the use of a well-known gospel choir to present the intervention video, whereas Fahrenwald et $a t^{28}$ included respected members of Native American tribes and their storytelling traditions to convey donation messages. There were significant differences in participant exposure; participants in Arriola's study were exposed to intervention materials in the home at several time points over a year (eg, through video, pamphlets and greetings cards), whereas Fahrenwald's participants received a short intervention lasting between 30 and $60 \mathrm{~min}$ that involved watching a video about organ donation followed by a group discussion.

Although these studies provide evidence of positive movement towards readiness to become an organ donor, sign a donor card or talk to family members about their preferences, whether those at a later stage of readiness actually signed a donor card is less clear. This issue is reflected in the UK community study where only a small proportion of participants who stated an intention to register in the future had done so at follow-up (A Warrens, personal communication, 2013).

\section{Mass media interventions}

All media interventions attempted to detect changes in the willingness or intention to join a donor register or sign a donor card. ${ }^{16}$ 29-32 However, interventions that solely utilised the mass media reported no significant change in the intention or willingness to register as an organ donor, despite focusing on a single ethnic group and undertaking formative research in the target population (see table 4 below). In contrast, a high level of success was achieved by one study ${ }^{15}$ which innovatively combined mass media techniques with interpersonal communication. This was conducted at the vehicle licensing office, a setting where individuals are able to join a state donor registry. Harrison $e t$ al set out with the clear aim of focusing on members of the population categorised as passive positives (ie, those favourable to organ donation but not yet joined the register). To determine the effect of each component of the intervention on registrations, the campaign occurred in three stages, each lasting 3 months. The interpersonal component of the intervention accounted for the greatest increase in registrants from 444 in the previous year to 5588 post campaign. Overall, the combined effect of the intervention components increased registrations by $700 \%$ (table 5).

\section{CONCLUSION}

This review identified 18 evaluated intervention studies focusing on ethnic minorities that were educational in nature, delivered in community settings or disseminated through the mass media. All but one study was conducted in the USA, with possible implications for generalising findings to different cultural contexts and minority populations. Other limitations of the review arise from the heterogeneity of study populations, measures and outcome variables, as well as the frequent use of unvalidated measures of knowledge. Also, there were limited data on the impact of specific facets of knowledge on registration or intent to register, thus failing to identify which 'knowledge gaps' are most important to address and whether this differs between ethnic groups. It is also notable that few studies explicitly mentioned an attempt to connect with the target population during the developmental phase and access acceptability. Reporting of important contextual information relating to the interventions was also sparse. Similar limitations of a lack of rigour and theory have also been noted in a recent review of smoking-related and obesity-related health promotion interventions adapted for ethnic minority populations. ${ }^{33}$ However, a detailed analysis of the process as well as the outcomes allowed us to identify some messages regarding effective approaches for increasing the acceptability and effectiveness of these interventions.

First, community-based educational interventions exhibited a higher level of success in terms of verified registration than those solely reliant on the mass media. Characteristics of interventions that were successful in increasing registration also tended to comprise a strong interpersonal element that focused on the particular population's concerns, delivered by members of the local community in familiar environments or in a context where individuals are required to make an immediate decision about registration. In contrast, mass media campaigns designed to promote organ donation to Hispanic and African American populations did not achieve an increase in registration. However, there was some evidence that media interventions successfully 
Table 5 Effect of media campaigns on donor registration

\begin{tabular}{|c|c|c|c|c|c|}
\hline $\begin{array}{l}\text { Author } \\
\text { Target } \\
\text { population } \\
\text { Language }\end{array}$ & $\begin{array}{l}\text { Media } \\
\text { Duration }\end{array}$ & $\begin{array}{l}\text { Self-reported registration } \\
\text { intention to be a donor }\end{array}$ & $\begin{array}{l}\text { Pretest } \\
\text { (\%) }\end{array}$ & $\begin{array}{l}\text { Post-test } \\
(\%)\end{array}$ & p Value \\
\hline $\begin{array}{l}\text { Frates et al, } \\
\text { USA } \\
\text { Hispanic } \\
\text { Spanish }\end{array}$ & $\begin{array}{l}\text { TV and radio } \\
3 \text { years }\end{array}$ & $\begin{array}{l}\text { Have decided to be a donor } \\
\text { Signed a donor card }\end{array}$ & $\begin{array}{l}27 \\
14\end{array}$ & $\begin{array}{l}31 \\
16\end{array}$ & $\begin{array}{l}0.163 \\
0.376\end{array}$ \\
\hline $\begin{array}{l}\text { Salim et al, } \\
\text { USA } \\
\text { Hispanic } \\
\text { English and } \\
\text { Spanish }\end{array}$ & $\begin{array}{l}\text { TV and radio } \\
1 \text { year }\end{array}$ & $\begin{array}{l}\text { Intent to donate ( } \% \text { likely or } \\
\text { very likely) }\end{array}$ & 32 & 30 & 0.488 \\
\hline $\begin{array}{l}\text { Radosevich } \\
\text { et al, }{ }^{16} \text { USA } \\
\text { African American } \\
\text { English }\end{array}$ & $\begin{array}{l}\text { TV, radio and print media } \\
1 \text { year }\end{array}$ & $\begin{array}{l}\text { Donor designation on driver's } \\
\text { licence }\end{array}$ & 33 & 40 & 0.123 \\
\hline $\begin{array}{l}\text { Alvaro et al, } \\
\text { USA } \\
\text { Hispanic } \\
\text { Spanish }\end{array}$ & $\begin{array}{l}\text { TV and radio } \\
1 \text { year }\end{array}$ & $\begin{array}{l}\text { Have you personally told } \\
\text { anybody that you would like } \\
\text { to be an organ donor (\%yes) }\end{array}$ & $\begin{array}{l}28.5 \\
23.2\end{array}$ & $\begin{array}{l}27.2 \\
20.9\end{array}$ & $\begin{array}{l}0.723 \\
0.445\end{array}$ \\
\hline $\begin{array}{l}\text { Hebert et } a{ }^{\beta 2 \star} \\
\text { Chinese } \\
\text { American } \\
\text { Not Stated }\end{array}$ & $\begin{array}{l}\text { Print media } \\
1 \text { year }\end{array}$ & $\begin{array}{l}\text { I do not intend to donate my } \\
\text { organ at my death }\end{array}$ & 11 & 21 & 0.001 \\
\hline $\begin{array}{l}\text { Harrison et al }{ }^{15} \\
\text { African American } \\
\text { English }\end{array}$ & $\begin{array}{l}\text { Bill Boards in the vicinity of vehicle } \\
\text { licensing office radio ads } \\
\text { Face-to-face contacts with donor } \\
\text { families }\end{array}$ & $\begin{array}{l}\text { Verified registration (counts of } \\
\text { registrants in postcode areas } \\
\text { with a population }>80 \% \\
\text { African American) }\end{array}$ & 0.1 & 1.2 & 0.001 \\
\hline
\end{tabular}

addressed knowledge gaps and misconceptions about organ donation. ${ }^{15} 3031$

Second, there are questions of whether registration always represents an appropriate outcome, given that ethnic minorities and those from socioeconomically deprived backgrounds are consistently shown to have more negative views, greater concerns and less knowledge about organ donation and transplantation compared with the general population. ${ }^{34-36}$ Interventions should therefore consider the intermediary steps through which individuals may need to pass before the desired endpoint of registration can be achieved, and also identify clearly at the outset the stage of readiness among the intervention participants and match interventions accordingly. Moving some sections of the population from an early stage of increased knowledge to actual registration may require multiple interventions that reinforce and build on each other over a period of time. In contrast, people who are further along the pathway and have reached an action stage may only require a limited 'nudge' or 'prompt' to register as an organ donor, through interventions involving behavioural prompts, cues to action and, where possible, an immediate opportunity to register. Indeed, our recent findings from a detailed focus group study of 229 Black and South Asian participants in London found that the majority of participants possessed extremely limited knowledge about organ donation, lacking specific knowledge about how to register and the elevated need for transplant among their ethnic group. ${ }^{37}$ While the focus group opened up a dialogue about donation and registration, it is unlikely that many participants would have been ready to sign up immediately for a variety of reasons including the need to discuss with their family, and for some people the desire to seek clarification from faith representatives. This is particularly prescient in the UK as recent data show $25 \%$ of ethnic minority families of potential donors who had formally signed the donor register refuse assent, ${ }^{38}$ with the current practice being to respect the wishes of the family regarding donation decisions even if this does not accord with those of the patient. 
Third, the review suggests that effective interventions for those in the precontemplation or contemplation phase are those undertaken in familiar community settings and delivered by appropriately trained lay individuals. In this context, lay health promoters have the benefit of an established rapport with the target population and the potential for gradual delivery of information that can be reinforced over time. Providing easy access to registration also has a significant impact on achieving increased sign-up, particularly for those at a later stage of the pathway from contemplation to behavioural outcome.

Current efforts to encourage organ donor registration in the UK have largely relied on mass media campaigns with some 'community engagement'. Although these have not been formally evaluated, there is little evidence of significant changes in overall registration rates. However, the present review suggests that these campaigns may have contributed to changes in knowledge, thus producing some shift along the pathway, although having less effect on registration practices. For the future, there is a need for rigorously conducted studies to assess the impact of specific facets of knowledge on registration or intent to register. There is also a need to develop robust intervention studies that take account of the population's readiness to sign the donor register, with approaches ranging from personal interaction and discussion with members of the lay community and facilitating a sign-up process in practice.

Acknowledgements The authors would like to thank Karen Welch for conducting the systematic search.

Contributors MM designed the review. SD led on the assessment of relevance and quality with CK and MM contributing. SD and MM analysed and interpreted the data and drafted the manuscript, with CK contributing. All authors approved the final version. MM is the guarantor.

Funding This article presents independent research funded by the National Institute for Health Research (NIHR) under its Programme Grants for Applied Research Programme (Grant Reference Number RP-PG-0707-10123). The views expressed in the paper are those of the authors and not necessarily those of the NHS, NIHR or the Department of Health.

\section{Competing interests None.}

Provenance and peer review Not commissioned; externally peer reviewed.

Data sharing statement No additional data are available.

Open Access This is an Open Access article distributed in accordance with the Creative Commons Attribution Non Commercial (CC BY-NC 3.0) license, which permits others to distribute, remix, adapt, build upon this work noncommercially, and license their derivative works on different terms, provided the original work is properly cited and the use is non-commercial. See: http:// creativecommons.org/licenses/by-nc/3.0/

\section{REFERENCES}

1. Hamm D, Tizzard J. Presumed consent for organ donation. BMJ 2008;336:230-0.

2. Office for National Statistics. Census: Ethnic group (write-in responses), local authorities in England and Wales. 2013. http:// www.ons.gov.uk/.../census/...census/...england-and-wales/rft-ct0010. xls (accessed 10 May 2013).

3. NHS Blood \& Transplant. Organ Donation and Transplantation Activity Report 2011-2012. 2012. http://www.organdonation.nhs.uk/ statistics/transplant activity report/current activity reports/ukt/ activity_report_2011_12.pdf (accessed 10 May 2013).

4. US Department for Health \& Human Services. 2011. http://www. organdonor.gov/whydonate/minorities.html (acessed 10 May 2013).

5. US Department of Health \& Human Services. 2013. http:// organdonor.gov/minortyaa/index.html (accessed 07 Aug 2013).

6. Morgan M, Kenten C, Deedat S. Attitudes to deceased organ donation and registration as a donor among minority ethnic groups in North America and the UK: a synthesis of quantitative and qualitative research. Ethn Health 2013;18:1-24.

7. Department of Health. Organs for transplant: a report of the Organ Donation Taskforce. 2008. http://www.dh.gov.uk (Search for: 9291)

8. Sharif A. Prioritising existing donors to receive organs would boost donation from ethnic minorities. BMJ 2012;347:f0536.

9. Higgins JP, Green S, Collaboration C. Cochrane handbook for systematic reviews of interventions. Wiley Online Library, 2008.

10. Jackson $\mathrm{N}$, Waters $\mathrm{E}$. Criteria for the systematic review of health promotion and public health interventions. Health Promot Int 2005;20:367-74.

11. Craig $P$, Dieppe $P$, Macintyre $S$, et al. Developing and evaluating complex interventions: the new Medical Research Council guidance. BMJ 2008;337:a1655.

12. Resnicow K, Andrews AM, Beach DK, et al. Randomized trial using hair stylists as lay health advisors to increase donation in African Americans. Ethn Dis 2010;20:276-81.

13. Andrews AM, Zhang N, Magee JC, et al. Increasing donor designation through black churches: results of a randomized trial. Prog Transplant 2012;22:161-7.

14. Arriola K, Robinson DH, Thompson NJ, et al. Project ACTS: an intervention to increase organ and tissue donation intentions among African Americans. Health Educ Behav 2009;37:264-74.

15. Harrison TR, Morgan SE, King AJ, et al. Saving lives branch by branch: the effectiveness of driver licensing bureau campaigns to promote organ donor registry sign-ups to African Americans in Michigan. J Health Commun 2011;16:805-19.

16. Radosevich DM, Larson SM, Scott T, et al. The effectiveness of the donate life-African American campaign in Minneapolis-St. Paul. In: Siegel JT, Alvaro EM, eds. Understanding organ donation: applied behavioral science perspectives. Wiley-Blackwell, 2010:64-82.

17. Thornton JD, Alejandro-Rodriguez M, Leon JB, et al. Effect of an iPod video intervention on consent to donate organs: a randomized trial. Ann Intern Med 2012;156:483-90.

18. Cárdenas V, Thornton JD, Wong KA, et al. Effects of classroom education on knowledge and attitudes regarding organ donation in ethnically diverse urban high schools. Clin Transplant 2010;24:784-93.

19. Feeley $\mathrm{TH}$, Anker AE, Watkins B, et al. A peer-to-peer campaign to promote organ donation among racially diverse college students in New York city. J Natl Med Assoc 2009;101:1154-62.

20. Alvaro EM, Siegel JT, Jones SP. Increasing organ donor registration rates by providing an immediate and complete registration opportunity: an experimental assessment of the IIFF model. Psychol Health Med 2011;16:686-94.

21. Horton RL, Horton PJ. A model of willingness to become a potential organ donor. Soc Sci Med 1991;33:1037-51.

22. Cantwell M, Clifford C. English nursing and medical students attitudes towards organ donation. J Adv Nurs 2000;32:961-8.

23. Morgan SE, Miller JK. Beyond the organ donor card: the effect of knowledge, attitudes, and values on willingness to communicate about organ donation to family members. J Health Commun 2002;14:121-34.

24. Salim A, Bery C, Ley EJ, et al. A focused educational program after religious services to improve organ donation in Hispanic Americans. Clin Transplant 2012;26:E634-40.

25. Callender CO, Hall MB, Branch D. An assessment of the effectiveness of the mottep model for increasing donation rates and preventing the need for transplantation-adult findings: program years 1998 and 1999. Semin Nephrol 2001;21:419-28.

26. Allen MD, Stillwater B. Organ donation and transplantation: a new tradition of sharing for Alaska natives. In: Siegel JT, Alvaro EM, eds. Understanding organ donation: applied behavioral science perspectives. Wiley-Blackwell, 2010:83-97 xxii, 368.

27. Prochaska JO, Velicer WF. The transtheoretical model of health behavior change. Am J Health Promot 1997;12:38-48.

28. Fahrenwald NL, Belitz C, Keckler A. 'Tribes sharing life': an organ donation educational intervention for american indian tribal college and university students. West $J$ Nurs Res 2011;33:901-15.

29. Frates J, Bohrer GG, Thomas D. Promoting organ donation to Hispanics: the role of the media and medicine. J Health Commun 2006;11:683-98. 
30. Salim A, Berry C, Ley EJ, et al. Utilizing the media to help increase organ donation in the Hispanic American population. Clin Transplant 2011;25:E622-8.

31. Alvaro EM, Jones SP, Robles AS, et al. Hispanic organ donation: impact of a Spanish-language organ donation campaign. J Natl Med Assoc 2006;98:28-35.

32. Hebert PL, Rivera J, Eng K, et al. Improving organ donation in Chinese communities in New York. In: Siegel JT, Alvaro EM, eds. Understanding organ donation: applied behavioral science perspectives. Wiley-Blackwell, 2010:119-31.

33. Liu J, Davidson E, Bhopal R, et al. Adapting health promotion interventions to meet the needs of ethnic minority groups: mixedmethods evidence synthesis. Health Technol Assess 2012;16:1-469.

34. Morgan M, Hooper R, Mayblin M, et al. Attitudes to kidney donation and registering as a donor among ethnic groups in the UK. J Public Health (Oxf) 2006;28:226-34.
35. Morgan SE, Miller JK, Arasaratnam LA. Similarities and differences between African Americans and European Americans attitudes knowledge, and willingness to communicate about organ donation. J Appl Soc Psychol 2003(4):693-715.

36. Rodrigue JR, Cornell DL, Howard RJ. Relationship of exposure to organ donation information to attitudes, beliefs, and donation decisions of next of kin. Prog Transplant 2009;19:173-9.

37. http://www.kcl.ac.uk/medicine/research/divisions/hscr/research/ groups/Long-Term-Conditions/current/donate/programme.aspx

38. NHSBT. One in four denied dying wish-Black and Asian families over-rule loved ones' decision to donate organs.

Secondary One in four denied dying wish-Black and Asian families over-rule loved ones' decision to donate organs 2011. http://www. nhsbt.nhs.uk/news/2011/newsrelease040311.html (accessed 10 Aug 2013) 